CURRENT RESEARCH JOURNAL OF PHILOLOGICAL SCIENCES 2(9): 54-58,

September 2021

DOI: https://doi.org/10.37547/philological-crjps-02-09-12

ISSN 2767-3758

(C)2021 Master Journals

Crossref doi

81 Google

Accepted24 $4^{\text {th }}$ September, 2021 \& Published $29^{\text {th }}$ September, 2021

\title{
KOREAN COMMUNICATION BEHAVIOR AND ITS PECULIARITIES
}

\author{
Nozimkhon Nodirjon Ogli Nosirkhonov
}

Master's Student, Tashkent State University Of Oriental Studies Scientific Supervisor: Phd. Yunusova G.D., Uzbekistan

\section{ABSTRACT}

This article focuses on the Korean people's communication skills and their peculiarities. It also provides information on Korean communication methods and application units. There is also talk of interrogation methods.

KEYWORDS: - Purpose of communication, communication behavior, greetings, units of appeal, formality in the appeal, respect in the appeal.

\section{INTRODUCTION}

When a person enters into a conversation, it is important for the speaker to articulate his or her point of view clearly and accurately. At the same time, it is natural that in the mind of the person who expresses the purpose, the approximate content of the expected response from the listener is also formed. Therefore, the speaker tries to deliver his speech in accordance with the expected answer. The ability to meet the demands that may arise during a conversation also largely depends on the speaker.

\section{T HE MAIN FINDINGS AND RESULTS}

In the Korean people, communication is based on the specific customs, values, and traditions of the Korean nation, and takes into account not only the logical content of the information, but also the identity, age, position, mood, feelings, and desires of the speaker. It can be said that the 주다 verb in the Korean language partially reflect the national character of the Korean people. In particular, this verb has a number of functions in speech when asking for something.

"언어 예절" is a very broad and complex topic of communication, which is inextricably linked with the history, customs, traditions and ancient values of the Korean nation. For foreign students aiming to learn Korean, this can be a challenge. T.Yu. Kaplan, who has done extensive research on this topic, attributes this to the fact that the Korean nation has 
CURRENT RESEARCH JOURNAL OF PHILOLOGICAL SCIENCES 2(9): 54-58,

September 2021

DOI: https://doi.org/10.37547/philological-crjps-02-09-12

ISSN 2767-3758

(C2021 Master Journals

Crossref doi

a well-established system of classifying society, and each class has its own way of communicating and addressing [1, p. 134]. At present, democratization has lost the importance of social boundaries in society, and the scope of individual communication has expanded significantly, making it more difficult to choose the appropriate approach. In addition, Korea has been an isolated state for many centuries, but today it actively cooperates with many countries, which affects not only its culture but also its language [2].

When it comes to communication style, Korean linguists divide appeals into two main types:

1. True appeal - the main task is to address the listener, to encourage him to understand the speech;

2. Assignment - Used in a conversation about a third party and serves as a reference in certain circumstances.

There are several factors involved in choosing this or that style of communication in Korean:

1. Formality (formal or informal communication processes)

2. Hierarchical characteristics (social status, age, sex of the applicant)

3. The level of closeness of communicators (the concept of "ours - a stranger", "acquaintance - a stranger".

There are the following communication categories in Korean:

1. 높임법 - respect category.

- 언니, 할머니께서는 오라고 하셨습니다. The nurse told my grandmother to come.

2. 완곡어법-rotation communication category. - 너 왜이렇게 쌀이 쪘니? - Why are you so obese?
In Korea, euphemisms are widely used, and they speak softly so as not to offend people. To put it mildly, the above statement is as follows:

- 요즘 더 건강해 보이나요. - Shu kunlarda sog'lom ko'rinyapsan.

3. 인사 법 - greeting and farewell category.

- 안 녕하십 니까? - Good morning!

- $\quad$ 안 녕! - Hello there!

- 안 녕히 가십시오! - Go well!

4. 호칭법과 지칭법- category of terms.

This category uses terms related to a particular profession, science, or field. The terms of kinship include:

- 아버지, 어디 계세요? - Dad, where are you?

- 안과 병둥에 근무하는 저 호사는 마음이

참 예쁘구나! - The nurse in the ophthalmology department was beautiful.

One of the peculiarities of the Korean way of communicating is that the use of pronouns in this language is different from other languages, especially in personal pronouns. These pronouns are seldom used in references, and names are used instead. The following is a list of the main lexical methods of addressing Korean language [1, p. 134]:

1. Name.

Koreans use surnames mainly as objects of reference and often use the following combination:

a) Last name (also name) + position, position, title;

b) Last name (also name) + nominal suffixes (for example -씨)

c) Last name (also name) + position, position, title + nominal suffixes (for example - 님, - 께서)

신부님, 저희들은 나쁜 일이라고는 아무것도 하지 않았어.[3, p. 119]

"Mr. Priest, we didn't do anything bad."

Addressing the speaker through a compound of name, position, title, or title serves to express the applicant's respect for the other person and raises the level of communication behavior to a certain level: 김종 일 선생 (Master Kim Chong Il). 
CURRENT RESEARCH JOURNAL OF PHILOLOGICAL SCIENCES 2(9): 54-58,

September 2021

DOI: https://doi.org/10.37547/philological-crjps-02-09-12

ISSN 2767-3758

(C2021 Master Journals

crossref do) 80 Google

Accepted24th September, 2021 \& Published 29th September, 2021

김씨, 이번 휴가는 어떻게 지내시렵 니까? [4, 59]

Mr. Kim, how are you going to spend this holiday?

김광성부장님이 허락하시거든 갔다오겠습니다.

[4, p. 49]

I will go if Kim Kwang Song allows the chief.

Addressing the listener in proportion to the level of kinship:

할머님, 저기 있는 옷도 다 보셨서요? [4, p. 120]

Grandma, have you seen all the clothes here?

Hospitality and respect for elders, which have long been a tradition, are one of the most important features of Korean character, and this tradition has been going on for centuries. It is said to bring up the younger generation in this spirit and to treat everyone with respect. Due to the unique nature of the Korean nation, it is absolutely impossible to study the issue of communication behavior without taking into account the national character, specific customs, values and traditions. Because communication is an integral part of the character of a nation and is closely intertwined. In Korean, words are always used to describe forms of evaluation (mutual respect and esteem) between speaker and listener. If the speaker is older and the listener is younger, the 낮춤말로 word is chosen, which means it is lower than its position. However, the 높임말 form of respect is used when addressing the majority, who are small in all respects, regardless of the position and age of the speaker. The form of respect for the subject
주체높임, which represents the form of respect, 으시 can be added not only to the verb, but also to the adjective, the noun, and the form.

부교수님은 곧 여기에 오십니까? [5, p. 203]

"Will the associate professor come here soon?"

그 인물이 누군지 아시겠소? [5, p. 204]

Does anyone know that person?

In any case, when they meet or say goodbye to acquaintances and strangers, the Korean people bow their heads lightly. It is also a way to show respect to someone you like or dislike. It is a wellknown fact that getting to know someone is a key part of communication. In social psychology, the term cognition refers to knowing not only the physical characteristics of an object, but also in terms of behavior, worldview, abilities, and emotions.

Another unique aspect of the Korean communication process is the variety of lexical layers used in the process of asking, asking for something or an action to be performed, as well as the presence of words that are appropriate for each situation. is a wealth of vocabulary. The following table shows what words a person uses and in what sense (command, request, demand, etc.) in the process of asking another person something in everyday conversation [6, pp. 13-16, 111-136]: 
CURRENT RESEARCH JOURNAL OF PHILOLOGICAL SCIENCES 2(9): 54-58,

September 2021

DOI: https://doi.org/10.37547/philological-crjps-02-09-12

ISSN 2767-3758

(C)2021 Master Journals

Crossref dof 81 Google

Accepted24th September, 2021 \& Published 29th September, 2021

\begin{tabular}{|c|c|}
\hline Ways to ask in communication & Number/percentage \\
\hline 인사말(Through greetings) & $10(7 \%)$ \\
\hline 부탁 (in the words of please) & $110(75 \%)$ \\
\hline 요구 (through demand words) & $19(13 \%)$ \\
\hline 명령(by command) & $7(5 \%)$ \\
\hline 합계 (Total analyzed cases) & $146(100 \%)$ \\
\hline
\end{tabular}

The table above shows that the use of pleas in Korean speech is one hundred to seventy-five percent, which also shows the importance of the topic chosen in our study. In addition, as a comment to this table, the most commonly used words in the application process are "잘 부탁드립니다", "잘 부탁합니다", “잘 부탁드릴게요”, “잘 부탁드리겠습니다”, “부탁드립니다”, “부탁 좀 드릴게요", “부탁 드려요", “부탁이 있어요", “부탁이 있는데”, “잘 부탁한다”, “부탁이야”, "부탁이다", “부탁 하나 하자”, “부탁해”, “부탁 하나만 하려고”, “부탁 좀 할게”, “제발 부탁인데요” and so on [6, pp. 13-16, 111-136].

\section{Conclusion}

In the process of communication, people not only get to know each other, but also determine what the relationship will be like in the future. It is also important to understand the interlocutor's behavior in a communication situation so that such a relationship is free and free from falsification. In Korean, the morphological structure of an emotive verb is expressed by suffixes that come before or after the base of the verb and belong to many (permanent or inflectional) grammatical categories that express proportion, gonorrhea (a polite form of address), tense, modality, type, cause. The structure of words that express the kindness, love, and respect that are characteristic of the Korean language, and their use in the literary text and language, is important for both the Korean people and those who are learning the language.

\section{ReFERENCES}

1. Kaplan T.Yu., Deryugina T.S. (2003) Speech etiquette of modern Korean. - Vladivostok: Publishing house of the Far Eastern State University. - p. 134.

2. South Korea is meant here because our 
CURRENT RESEARCH JOURNAL OF PHILOLOGICAL SCIENCES 2(9): 54-58,

September 2021

DOI: https://doi.org/10.37547/philological-crjps-02-09-12

ISSN 2767-3758

(C)2021 Master Journals

Crossref do: 81 Google

Accepted24th September, 2021 \& Published 29th September, 2021

work is mainly on the example of the Seoul

dialect.

3. 침묵. 엔도 슈사쿠. 홍성사. - 서울. 2000. -

P 119.

4. 한국어 $4, \quad$ 한국어문화연수부편.

고려대학교 민족 문화연구소, 2003.

(Annual collection of Korean stories). 2003.

- P 120.

5. 침묵. 엔도 슈사쿠. 홍성사. - 서울. 2000. P 204.

6. '부탁' 관련 표현에 대한 한국인과 외국인의 인식 차이 분석 - 드라마 말뭉치를 기반으로. 장 미 미. Journal of the International Network for Korean Language and Culture. - P 13-16, 111-136. 